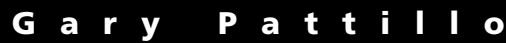

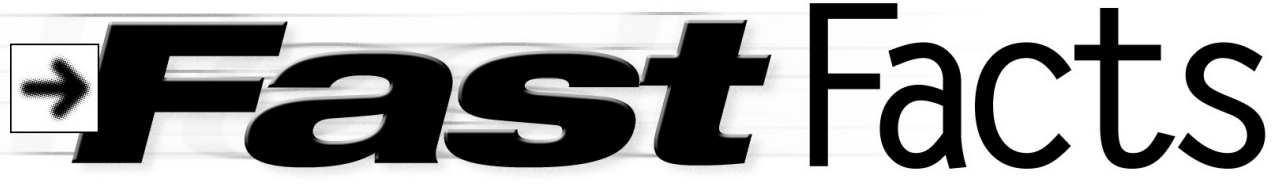

Print books

Despite the popularity of e-books, traditional U.S. print title output in 2010 increased 5 percent. Output of new traditional titles and editions increased from 302,410 in 2009 to 316,480 in 2010. Print-On-Demand titles increased 169 percent from 1,033,065 in 2009 to 2,776,260 in 2010. Science and technology publishing increased while literature and poetry publishing declined.

"Print isn't dead, says Bowker's Annual Book Production Report," Bowker, www.bowker.com/index.php/press-releases /633-print-isnt-dead-says-bowkers-annual-book-production-report (retrieved September 1, 2011).

\section{$\rightarrow$ Global university rankings}

Trends in recent years demonstrate that the number of global university rankings in various publications is likely to keep growing, although they will become more specialized. Despite their many shortcomings, biases, and flaws "rankings enjoy a high level of acceptance among stakeholders and the wider public because of their simplicity and consumer-type information." Due to the elitist approach applied in the ranking methodologies, more than 16,000 of the world's universities will never obtain any rank in global university rankings.

Andrejs Rauhvargers, 2011 Global university rankings and their impact, European University Association, www.eua.be /pubs/Global_University_Rankings_and_Their_Impact.pdf (retrieved December 6, 2011).
\end{abstract}

\section{Google's metadata}

Geoffrey Nunberg, the scholar who argued in 2009 that Google Books metadata were "a mishmash wrapped in a muddle wrapped in a mess," maintains that nothing much has changed. While Google has corrected errors in some specific records, "the changes are a drop in a greatly enlarged ocean," he said, adding that the flaws in Google's metadata remain "a big systematic structural problem." The company, he says, is not "good at the punctilious, anal-retentive sort of work librarians are used to." Matthew Reisz, "Do You Feel Lucky? Google Books is at Heart a Catalogue of Errors," Times Higher Education, www. timeshighereducation.co.uk/story.asp?sectioncode $=26 \&$ storycode $=418378 \& c=1$ (retrieved December 8, 2011).

\section{The nation's report card}

The average math scores among the nation's fourth and eighth-grade students have continued to rise on standardized tests since 1990. Reading comprehension scores, while improving slightly, have remained relatively flat over the same time period. The trend in percentage of fourth-graders who read regularly for fun, however, is higher than in the previous five years. Since 2009, Missouri was the only state to record declines in both reading and math scores. Hawaii was the only state to improve in both subjects at both grade levels.

"The Nation's Report Card: Findings in Brief, Reading and Mathematics 2011, National Assessment of Education Progress at Grades 4 and 8, NCES 2012-459," Institute of Education Sciences, National Center for Education Statistics, U.S. Department of Education, http://nces.ed.gov/nationsreportcard/pdf/main2011/2012459.pdf (retrieved December 6, 2011).

\section{$\rightarrow$ Google verbatim}

Google search has rolled out a new "verbatim search tool" under "More search tools" on the left-hand side of their search results page. The verbatim tool forces Google to search using your exact terms, rather than expanding and "improving" more general searches. It removes spelling corrections, synonyms, personal data, and more, so that the search engine will use the literal words you entered without making automatic changes as is usually the case.

"Search using your terms, verbatim," Google, http://insidesearch.blogspot.com/2011/11/search-using-your-terms-verbatim html (retrieved December 2, 2011).

Gary Pattillo is reference librarian at the University of North Carolina-Chapel Hill, e-mail: pattillo@ email.unc.edu 